\title{
Genetic evidence reveals a unique lineage of Bryde's whales in the northern Gulf of Mexico
}

\author{
Patricia E. Rosel*, Lynsey A. Wilcox \\ National Marine Fisheries Service, 646 Cajundome Blvd, Lafayette, Louisiana 70506, USA
}

\begin{abstract}
Bryde's whales Balaenoptera edeni are the only year-round resident baleen whale species in the northern Gulf of Mexico (GOMx). The current population abundance estimate is 33 (CV 1.07) and the population is severely restricted in range. We characterized genetic diversity and phylogenetic relationships of these whales to other members of the Bryde's whale complex. We analyzed DNA sequence data from 3 mitochondrial DNA (mtDNA) and 9 nuclear genes, and examined 42 nuclear microsatellite loci for 21 Bryde's whale samples collected in the GOMx and 2 from the western North Atlantic. mtDNA diversity was extremely low; only 2 haplotypes were found in the first $375 \mathrm{bp}$ of the control region and no variability in cytb or cox 1 genes was seen. Twenty-five microsatellite loci were monomorphic, 16 had 2 or 3 alleles, and 1 had 4 alleles. Most nuclear genes exhibited shared alleles across balaenopterid species. Phylogenetic reconstruction using the control region and all published Bryde's whale sequences revealed that GOMx Bryde's whale haplotypes are evolutionarily distinct from other members of the Bryde's whale complex examined to date. Within the first $375 \mathrm{bp}$ of the control region, we found 25-26 fixed differences between GOMx haplotypes and those from sei whales and the 2 recognized Bryde's whale subspecies. The GOMx whales are as divergent as these subspecies and species are from each other. The level of divergence suggests a unique evolutionary trajectory worthy of its own taxonomic standing. The small population size and markedly low genetic diversity raise conservation concern for this unique group of whales.
\end{abstract}

KEY WORDS: Bryde's whale complex - Balaenoptera edeni $\cdot$ Mitochondrial DNA - Control region $\cdot$ Cetacean

Resale or republication not permitted without written consent of the publisher

\section{INTRODUCTION}

Fourteen baleen whale species are currently recognized in 4 families. Of these 14 species, 5 are listed as Endangered by the IUCN, 4 are Data Deficient and 5 are Species of Least Concern (IUCN 2012). However, it is likely that additional species exist but are currently not recognized and therefore are afforded few protections. A case in point is the Bryde's whale complex, a group of baleen whales in which the identity and number of species is unresolved. Currently, 2 forms of Bryde's whales are recognized, differing most obviously in size. The smaller form, Eden's whale, was described first by Anderson (1879) as Balaenoptera edeni from an animal that stranded in Myanmar. These whales are thought to be sexually mature at lengths that rarely exceed $11.5 \mathrm{~m}$ and they inhabit primarily coastal and continental shelf waters of the northern Indian Ocean and the western Pacific Ocean (Rice 1998). A larger form of Bryde's whale was first described by Olsen (1913) as B. brydei from whales harvested off South Africa, primarily at a whaling station in Saldanha Bay on the west coast of South Africa. These whales reach $14-15 \mathrm{~m}$ in total length, and inhabit tropical and warm temperate waters worldwide (Rice 1998). Following these initial species descriptions, Junge (1950) synonymized (as $B$. edeni) the 2 species based on a morpho- 
logical comparison of skull and skeletal remains. He concluded that the individual variability in the characters he examined was so broad that the 2 species should be considered conspecific. Several morphological comparisons of Bryde's-type whales found in other parts of the world followed into the 1990s (e.g. Best 1960, 1977, Soot-Ryen 1961, Perrin et al. 1996), but with no resolution as to whether there are 2 species or just one. The discovery of potentially parapatric ecotypes off South Africa that differ in size, prey preference, and migratory movements (Best 1977, 2001) further complicated matters.

Omura's whale B. omurai has also been considered a member of the Bryde's whale complex. This species was more recently described based on morphological and allozyme differences (Wada et al. 2003). It was first identified from the Solomon Islands, southern Japan (holotype), and the Cocos Islands in the eastern Indian Ocean (Wada et al. 2003), and later in Taiwan, Thailand, and the Philippines (Yamada et al. 2006, 2008). In a morphological comparison of $B$. omurai with other members of the Bryde's whale complex, Wada et al. (2003) suggested that B. omurai and the $2 B$. edeni forms have diagnostic features in the shape of the maxilla and frontal bones that can be used to separate them, and the authors concluded all 3 should be considered distinct species: $B$. omurai, B. edeni, and B. brydei.

More recently, molecular genetic data have been applied to the Bryde's whale complex. Sasaki et al. (2006) constructed a phylogeny using 12 mitochondrial protein-coding genes. The authors utilized samples from specimens of each of the 3 species proposed by Wada et al. (2003); specimens were identified to species using the diagnostic morphological characters described by Wada et al. (2003). Maximum likelihood analysis resulted in 3 well-supported clades corresponding to the taxa proposed by Wada et al. (2003) and revealed that Omura's whale has an extended, independent evolutionary history (Sasaki et al. 2006). The authors concluded that the mitochondrial DNA (mtDNA) data support recognition of all 3 taxonomic units as species. Molecular studies have also consistently grouped the sei whale $B$. borealis in a larger clade containing the 2 Bryde's whale taxa to the exclusion of Omura's whale (Sasaki et al. 2006, Agnarsson \& May-Collado 2008, McGowen \& Gatesy 2009), suggesting that sei whales might well be considered a member of this complex.

Taxonomic uncertainties remain. Kato \& Perrin (2009) suggested that the type specimen used to describe Eden's whale $B$. edeni could have been an Omura's whale. If true, this significantly complicates

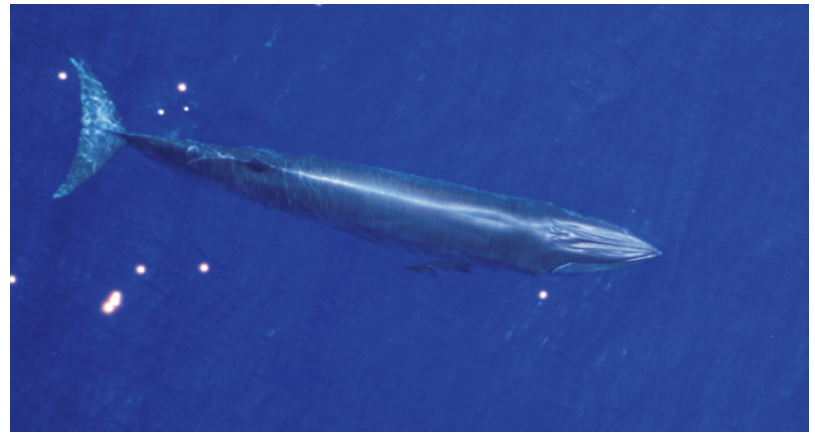

Fig. 1. Bryde's whale Balaenoptera edeni, photographed in the northern Gulf of Mexico. Image: National Marine Fisheries Service under permit 738 (P77\#51)

efforts to apply correct taxonomic names to the members of this complex. To date, the Society for Marine Mammalogy's Committee on Taxonomy (Committee on Taxonomy 2011) follows the recommendation of Rice (1998) and recognizes only 2 species, B. edeni and $B$. omurai, with 2 subspecies in $B$. edeni: the smaller form B. e. edeni and the larger form $B$. e. brydei. We follow this nomenclature and we also use the name 'Bryde's whale' to collectively refer to $B$. e. edeni and $B$. e. brydei.

Visual (Waring et al. 2013) and acoustic (Rice et al. 2014) data indicate that Bryde's whales reside yearround in a restricted area in the northern Gulf of Mexico (GOMx). These whales exhibit the 3 longitudinal rostral ridges characteristic of Bryde's whales elsewhere (Fig. 1). Rice (1998) attributes records of Bryde's whales in the Atlantic Ocean to the larger form, B e. brydei. More recently, Luksenburg (2012) sequenced the mtDNA control region for 2 Bryde's whales that stranded in Aruba and classified them as B. e. brydei. The phylogenetic relationship of Bryde's whales in the GOMx to Bryde's whales elsewhere has not yet been examined. As a result, whether they belong to $B$. e. brydei or $B$. e. edeni is unknown. Abundance estimates based on shipboard surveys reveal a very small population size $(n=33, C V=1.07$; Waring et al. 2013). The recent oil spill in the GOMx highlights the need for a better understanding of the taxonomic status of this small population. In this study, we examine the genetic diversity and phylogenetic relationship of Bryde's whales in the GOMx to other Bryde's whales worldwide.

\section{MATERIALS AND METHODS}

Skin biopsy samples $(\mathrm{n}=20)$ and tissue from 3 stranded animals were collected from Bryde's whales 
in the northeastern GOMx over the period 19922011 and from 2 Bryde's whales that stranded in North and South Carolina in the western North Atlantic (Fig. 2). DNA was extracted using standard proteinase $\mathrm{K}$ digestion followed by organic extraction (Rosel \& Block 1996) or using a DNeasy Blood and Tissue kit (Qiagen) following the manufacturer's protocol. DNA quality and quantity were assessed through gel electrophoresis and fluorometry (Hoefer DyNA Quant 200 fluorometer, GE Healthcare), respectively. For comparisons among other balaenopterid species, we also extracted DNA from a blue (Balaenoptera musculus), fin (B. physalus), sei (B. borealis), minke (B. acutorostrata), and humpback (Megaptera novaeangliae) whale and, as an outgroup, a North Atlantic right whale Eubalaena glacialis. All whale samples were from US waters of the western North Atlantic. When necessary, the sex of samples was determined through PCR amplification of fragments of the ZFY and ZFX genes following Bérubé \& Palsbøll (1996). Reactions contained $25 \mathrm{ng}$ of DNA, $20 \mathrm{mM}$ Tris- $\mathrm{HCl}(\mathrm{pH} 8.4), 50 \mathrm{mM} \mathrm{KCl}$, $1.5 \mathrm{mM} \mathrm{MgCl} 2,150 \mu \mathrm{M}$ dNTPs, 1 U Taq DNA Polymerase (Invitrogen), and $0.3 \mu \mathrm{M}$ of each primer. When needed, $0.24 \mathrm{mg} \mathrm{ml}^{-1}$ bovine serum albumin (BSA; Sigma-Aldrich) was added to reactions to enhance amplification. PCR amplification was performed using an initial denaturation step of $94^{\circ} \mathrm{C}$ for $5 \mathrm{~min}$ followed by 35 cycles of $94^{\circ} \mathrm{C}$ for $40 \mathrm{~s}, 52^{\circ} \mathrm{C}$ for $40 \mathrm{~s}$, and $72^{\circ} \mathrm{C}$ for $40 \mathrm{~s}$ with a final extension step at $72^{\circ} \mathrm{C}$ for $5 \mathrm{~min}$. The ZFX0923R primer was added to the reactions during the 7th cycle of the PCR profile (Lopes et al. 1999, Adams \& Rosel 2006). PCR products, including those from positive males and females identified via morphology, were viewed on a $2.5 \%$ agarose gel to determine the sex of each sample.

The complete mtDNA control region was sequenced in 2 overlapping fragments for all GOMx Bryde's whale samples as well as 1 representative of 6 other baleen whale species. We amplified and sequenced the $5^{\prime}$ end of the control region using primers L15824 and H16265 (Rosel et al. 1999) or L15824 and H16498 (Rosel et al. 1994). The PCR profile included $95^{\circ} \mathrm{C}$ for $30 \mathrm{~s}$ followed by $30-35$ cycles of $95^{\circ} \mathrm{C}$ for $30 \mathrm{~s}, 55^{\circ} \mathrm{C}$ for $30 \mathrm{~s}$, and $72^{\circ} \mathrm{C}$ for $30 \mathrm{~s}$ with a final $7 \min 72^{\circ} \mathrm{C}$ extension. We used 2-50 ng of DNA in $25 \mu \mathrm{l}$ reactions with $20 \mathrm{mM}$ Tris- $\mathrm{HCl}(\mathrm{pH} 8.4), 50 \mathrm{mM} \mathrm{KCl}$, $1.5 \mathrm{mM} \mathrm{MgCl} 2,150 \mu \mathrm{M}$ dNTPs, 1.0-2.0 U Taq DNA Polymerase (Invitrogen), and $0.3 \mu \mathrm{M}$ of each primer. When needed, BSA was added to reactions at a final concentration of $0.16-0.32 \mathrm{mg} \mathrm{ml}^{-1}$. The $3^{\prime}$ end of the control region was amplified using primers L16061 (Tolley \& Rosel 2006) and H00651 (Kocher et al. 1989) as above using 36 cycles, an annealing temperature of $52^{\circ} \mathrm{C}$ and a final $72^{\circ} \mathrm{C}$ extension step for $10 \mathrm{~min}$. Gel electrophoresis was used to view amplification efficiency and to check for contamination in no-DNA controls. All PCR products were purified via low melting point agarose gel extraction followed by agarase digestion, and sequenced in both directions using Applied Biosystems BigDye Terminator v1.1 cycle sequencing kit and an AB3130 Genetic Ana-

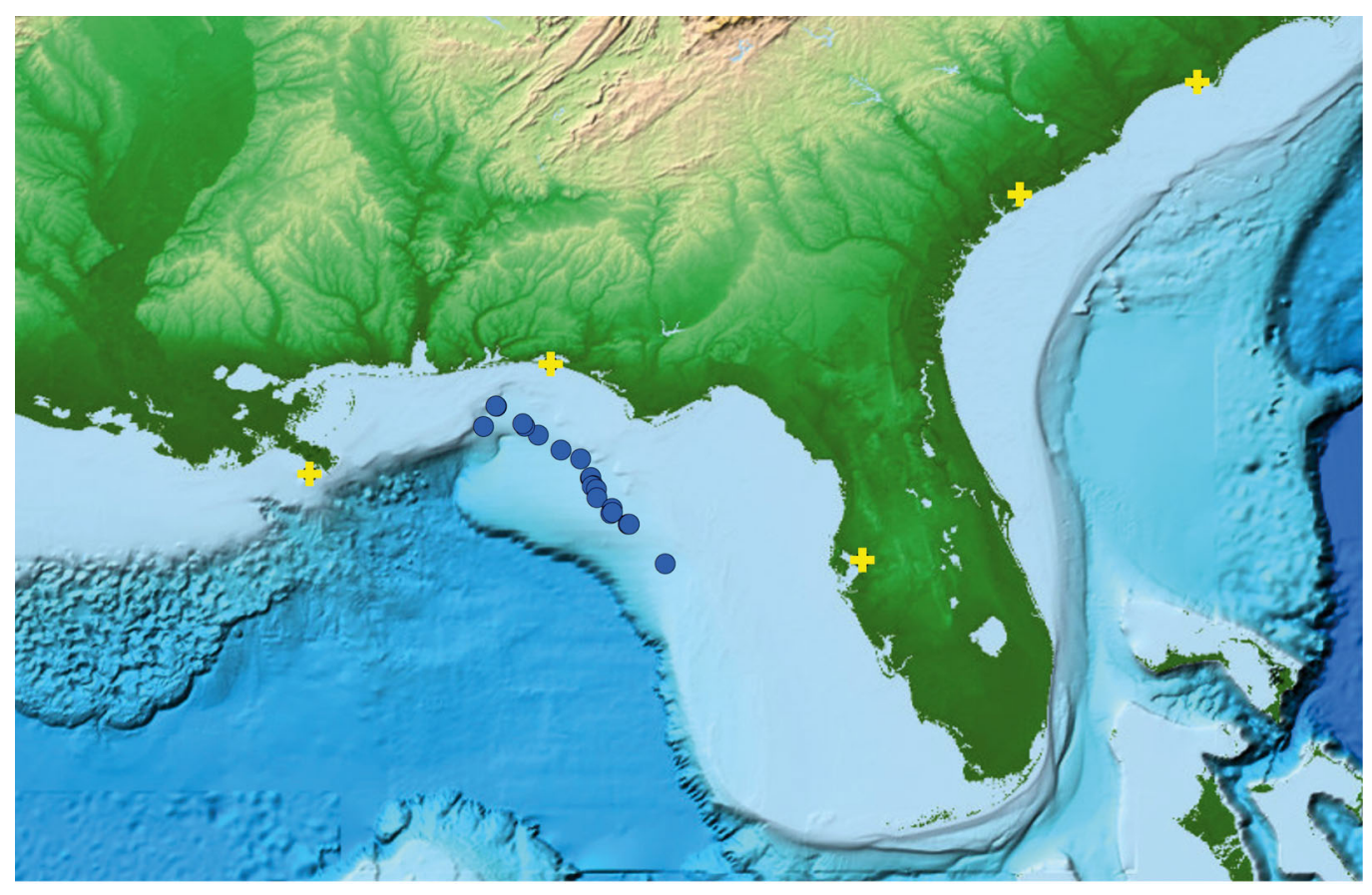

Fig. 2. Locations for Bryde's whale biopsy samples $(O)$ and stranding samples (1) collected in the western North Atlantic Ocean and the Gulf of Mexico. ETOPO1 basemap is from Amante \& Eakins (2009). Hillshade visualization is by $\mathrm{J}$. Varner and E. Lim (CIRES, University of Colorado at Boulder and NOAA/NGDC) 
lyzer. Forward and reverse reads were edited using either Sequencher 5.0.1 (GeneCodes) or Sequence Navigator 1.0.1 (Applied Biosystems) and a consensus sequence of the 2 reads was created for each sample.

We similarly amplified and sequenced the full mitochondrial cytochrome $b$ gene (cytb, $1140 \mathrm{bp}$ ) for 5 Bryde's whale samples as well as 6 other baleen whale species and the 'barcoding' region of the mitochondrial cytochrome oxidase gene (cox1) for 5 GOMx Bryde's whale samples and 1 blue and 1 right whale. cox1 sequences for the remaining 4 species were taken from Viricel \& Rosel (2012). The cytb gene was amplified in 2 overlapping fragments using primer sets L14724 (Palumbi et al. 1991) and H15387 (Rosel et al. 1994) and newly designed primers for the downstream half of the cytb gene (L15363 5'-CAY GAA ACA GGA TCC AA-3' and H15813 5'-CTT GAG TCT TAG GGA G-3'; gene locations for the 2 new primers are numbered following Irwin et al. [1991] and the complete fin whale mitochondrial genome [GenBank X61145], respectively). The PCR profile consisted of $95^{\circ} \mathrm{C}$ for $30 \mathrm{~s}$ followed by 35 cycles of $95^{\circ} \mathrm{C}$ for $30 \mathrm{~s}, 50^{\circ} \mathrm{C}$ for $30 \mathrm{~s}$, and $72^{\circ} \mathrm{C}$ for $30 \mathrm{~s}$ with a final $72^{\circ} \mathrm{C}$ extension for $7 \mathrm{~min}$ and reagent concentrations as described above for the control region amplification. A $731 \mathrm{bp}$ fragment of the cox1 gene was amplified following Viricel \& Rosel (2012). MacClade 4.0.8 (Maddison \& Maddison 2000) was used to collapse sequences to haplotypes and the resultant haplotypes were aligned with sequences from GenBank using MUSCLE 3.8.31 (Edgar 2004) (www.ebi.ac.uk/Tools/msa/muscle/) and default parameters.

Two different control region alignments were created based on the length of balaenopterid sequences available in GenBank (see Table S1a in the Supplement at www.int-res.com/articles/suppl/n025p019_ supp.pdf). The primary alignment used for all analyses was 375 bp long and contained 39 haplotypes (representing 90 individuals). A shorter alignment of $305 \mathrm{bp}$ containing 86 haplotypes (representing 510 individuals) differed from the $375 \mathrm{bp}$ alignment in that it included 43 additional B. e. brydei haplotypes from Kanda et al. (2007) and 4 B. e. brydei haplotypes from Kershaw et al. (2013). This shorter alignment was used only for phylogenetic analysis to expand geographic sampling coverage of $B$. e. brydei and examine taxonomic affinities of the sequences of Kanda et al. (2007) and Kershaw et al. (2013). For the protein coding genes, we augmented our new cytb and $\operatorname{cox} 1$ sequences with additional sequences from GenBank (see Table S1b,c in the Supplement) and created a concatenated alignment. This alignment included $421 \mathrm{bp}$ of the 5' end of cytb (shortened from our full-length sequences to accommodate shorter sequences from GenBank) and 653bp of cox1.

Arlequin 3.5.1.2 (Excoffier \& Lischer 2010) was used to estimate control region haplotypic (Nei \& Tajima 1981) and nucleotide (Nei 1987) diversities for the GOMx whales. Net within- and between-group nucleotide divergence $\left(d_{\mathrm{A} i}\right.$ Nei (1987)) was estimated for pairwise comparisons between the GOMx haplotypes and $B$. e. brydei, $B$. e. edeni, B. borealis, and $B$. omurai sequences from GenBank using MEGA 5.2 (Tamura et al. 2011) for the 375 bp alignment. MEGA was used to estimate the best model of evolution from which to make the divergence estimates - a Tamura 3 -parameter model (Tamura 1992) with gamma correction $(\alpha=0.39)$.

Phylogenetic reconstructions were derived using our newly obtained control region sequences combined with sequences acquired from GenBank (see Table S1a in the Supplement). We applied MrBayes 3.2.1 (Huelsenbeck \& Ronquist 2001) to the 305 and $375 \mathrm{bp}$ control region alignments using the CIPRES Science Gateway (Miller et al. 2010). jModeltest (Posada 2008) and the Bayesian information criterion (BIC) were used to determine the best model given the alignments: TIM+G and TPM+G for the 305 and $375 \mathrm{bp}$ control region alignments, respectively. As a result, the more parameterized general time reversible (GTR) model with appropriate corrections (gamma and/or invariable sites) was used. Bayesian searches involved 4 chains, 2 runs, and 5000000 generations using default priors in MrBayes. Burn-in was set to $25 \%$. Convergence of the runs was determined by examining the average standard deviation of split frequencies and using Tracer 1.5 (Rambaut \& Drummond 2007). MrBayes was also used as above to analyze the concatenated alignment of the 2 protein coding genes. We partitioned the concatenated data set by gene and applied the individual best models of evolution identified by jModeltest $(\operatorname{TrN}+\mathrm{I}$ for $c y t b_{i} \mathrm{HKY}+\mathrm{G}$ for cox1).

Due to the taxonomic uncertainty within the Bryde's whale complex, it is possible that GenBank accessions are incorrectly identified to species. To most accurately identify species clades on our phylogenetic trees, we used the sequences from Sasaki et al. (2006) to represent correctly identified specimens, as these authors sequenced 4 samples $(2 \mathrm{~B}$. omurai, $1 \mathrm{~B}$. e. edeni, and $1 \mathrm{~B}$. e. brydei) morphologically classified to species following Wada et al. (2003). Placement of these morphologically classified specimens was used to identify the clades corresponding 
to each of the 3 taxonomic groups. Finally, following Kershaw et al. (2013), we applied characteristic attributes (CAs) diagnosis (Davis \& Nixon 1992, Sarkar et al. 2002, Lowenstein et al. 2009) to controlregion sequences of $B$. e. edeni, B. e. brydei, B. omurai, and the haplotypes from the GOMx whales. We first used the 9 diagnostic sites identified by Kershaw et al. (2013) to try to classify the GOMx Bryde's whales to the recognized subspecies. Second, we performed the CAs analysis de novo using the phylogenetic reconstruction produced by our 305 bp alignment. This tree was used to identify the clades corresponding to each taxon and we then identified those nucleotide positions that were unique to each of the clades to determine whether the GOMx Bryde's whales exhibited diagnostic characters of their own.

To examine nuclear genetic diversity of Bryde's whales in the GOMx, we tested 54 microsatellite loci originally developed for, and found to be polymorphic in, other cetacean species (see Table S1d in the Supplement). Loci were first tested using 2-4 GOMx Bryde's whale samples in order to determine whether they would amplify. The following conditions were used: $20 \mu \mathrm{l}$ reactions of $20 \mathrm{mM}$ Tris- $\mathrm{HCl}(\mathrm{pH} 8.4)$, $50 \mathrm{mM} \mathrm{KCl}, 1.5 \mathrm{mM} \mathrm{MgCl}_{2}, 150 \mu \mathrm{M}$ dNTPs, $0.6 \mathrm{U}$ Taq DNA Polymerase (Invitrogen), $0.15-0.3 \mu \mathrm{M}$ of each primer, and 25 ng of DNA. The PCR profile included an initial denaturation step at $94^{\circ} \mathrm{C}$ for $30 \mathrm{~s}$ followed by $28-30$ cycles of $94^{\circ} \mathrm{C}$ for $30 \mathrm{~s}, 45-62^{\circ} \mathrm{C}$ for $30 \mathrm{~s}$, and $72^{\circ} \mathrm{C}$ for $30 \mathrm{~s}$ with a final $72^{\circ} \mathrm{C}$ extension for 10 min (see Table S1e in the Supplement for final loci and PCR conditions). Amplified products were run on an AB310 or AB3130 Genetic Analyzer using the GS500TAMRA or GS-500LIZ size standard, respectively, and genotypes determined using Genotyper 2.5 or GeneMapper 5 (Applied Biosystems). The polymorphic loci that were retained for the study $(n=17)$ were genotyped for all the GOMx Bryde's whale samples. We tested for Hardy-Weinberg equilibrium (HWE) and linkage disequilibrium using Genepop 4.0.1 (Rousset 2008) and default settings. Microchecker 2.2.3 (Van Oosterhout et al. 2004) was used to test each locus for the presence of genotyping errors due to null alleles, allelic dropout, and incorrect scoring of stutter. We re-genotyped 4 samples $(17 \%)$ at all loci, $50 \%$ of the samples were repeated for 4 loci, and $8-12 \%$ were repeated for 10 loci. No differences were found in any of the repeated loci. In order to identify whether an individual whale had been sampled more than once, we used the Microsatellite Toolkit (Park 2001) to search for individuals with identical multilocus genotypes and we estimated probability of identity $P_{(\mathrm{ID})}$ and the more con- servative $P_{(\mathrm{ID}) \text { sib }}$ (Waits et al. 2001) using GenAlEx 6 (Peakall \& Smouse 2006) to determine the likelihood that 2 individuals would share genotypes by chance. Samples identified as having identical genotypes were also checked to see that they had the same sex and the same mtDNA sequence. Genetic diversity was summarized as observed and expected heterozygosity using Arlequin 3.5 (Excoffier \& Lischer 2010) and number of alleles and allelic richness using FSTAT 2.9.3.2 (Goudet 1995).

Finally, we also amplified and sequenced a total of 4908 bp of DNA across 9 nuclear loci (Table 1) for 1 GOMx Bryde's whale, 1 fin whale, and 1 sei whale, all from the North Atlantic Ocean. Amplification reactions contained $25 \mathrm{ng}$ DNA, $20 \mathrm{mM}$ Tris- $\mathrm{HCl}$ (pH 8.4), $50 \mathrm{mM} \mathrm{KCl}, 1.5 \mathrm{mM} \mathrm{MgCl}_{2}, 150 \mu \mathrm{M}$ dNTPs, $1 \mathrm{U}$ Taq DNA Polymerase (Invitrogen), and $0.3 \mu \mathrm{M}$ of each primer and used PCR profiles provided in Table 1. Where available, sequences of both Bryde's whale subspecies, fin, sei, and Omura's whales from GenBank were downloaded for additional comparison (see Table S1f in the Supplement). Three loci span exons (ADRB2, ATP7A, and BDNF), one spans a 3-untranslated region (APP-3 UTR), four are likely to span introns (CHRNA1, F9, G6PD, and MGF) and the location of the tenth is unknown (INT) (Vollmer \& Rosel 2012).

\section{RESULTS}

DNA was successfully extracted and sequenced from 23 Bryde's whales sampled in the GOMx and 2 whales that stranded in the western North Atlantic Ocean. Two of the stranded samples were identified as females in the field, and molecular sexing of the remaining 23 samples revealed 12 females and 11 males. Although estimates of $P_{(\mathrm{ID})}\left(1.55 \times 10^{-4}\right)$ and $P_{\text {(ID)sibs }}\left(1.40 \times 10^{-2}\right)$ were fairly high, we identified 2 sets of duplicates based on the microsatellite data, sex, and control-region haplotype. One whale was biopsied twice on the same day and the second whale was sampled in 2007 and again in 2010 in the GOMx. One member of each duplicate was removed from all analyses, leaving a final sample size of 23.

Over the first $375 \mathrm{bp}$ of the control region, 21 GOMx Bryde's whale samples shared the same haplotype, while the 2 remaining samples shared a heteroplasmic position at a single site. Depending on which base is called, the heteroplasmic sequence was either identical to the other haplotype or exhibited a single transitional difference. Sequencing the rest of the control region revealed only 1 additional 
Table 1. Variability in nuclear loci among members of the Bryde's whale complex. For each locus, a single individual of Balaenoptera borealis, B. edeni (Gulf of Mexico [GOMx]), and B. physalus (as a more distant balaenopterid) was sequenced and those sequences were augmented with available GenBank data. Shown are total sequence length in base pairs of new sequences (final alignment length upon addition of GenBank sequences), taxa and number of variable sites (and insertion deletion events) in the alignment, and whether any species shared alleles at the locus

\begin{tabular}{|c|c|c|c|c|}
\hline Locus & $\begin{array}{l}\text { Sequence } \\
\text { length }\end{array}$ & $\begin{array}{l}\text { Taxa in } \\
\text { alignment }\end{array}$ & $\begin{array}{l}\text { Variable sites } \\
\quad \text { (indels) }\end{array}$ & Share allele? \\
\hline $\mathrm{ADRB}^{\mathrm{a}}$ & 790 & $\begin{array}{l}\text { B. } \text { edeni }(\mathrm{GOMx}) \mathrm{n}=1 \\
\text { B. borealis } \mathrm{n}=1 \\
\text { B. } \text { physalus } \mathrm{n}=1\end{array}$ & 2 & B. borealis and B. physalus \\
\hline $\mathrm{APP}^{\mathrm{b}}$ & 652 & $\begin{array}{l}\text { B. edeni }(\mathrm{GOMx}) \mathrm{n}=1 \\
\text { B. borealis } \mathrm{n}=1 \\
\text { B. physalus } \mathrm{n}=1\end{array}$ & 3 & None \\
\hline ATP7A $^{b}$ & 677 & $\begin{array}{l}\text { B. } \text { edeni }(\mathrm{GOMx}) \mathrm{n}=1 \\
\text { B. } \text { edeni }^{\mathrm{C}} \mathrm{n}=1 \\
\text { B. borealis } \mathrm{n}=2 \\
\text { B. } \text { physalus } \mathrm{n}=2\end{array}$ & 6 & B. edeni $(\mathrm{GOMx})$ and B. edeni ${ }^{\mathrm{c}}$ \\
\hline $\mathrm{BDNF}^{\mathrm{b}}$ & $555(515)$ & $\begin{array}{l}\text { B. edeni }(\mathrm{GOMx}) \mathrm{n}=1 \\
\text { B. } \text { edeni }^{\mathrm{C}} \mathrm{n}=1 \\
\text { B. } \text { borealis } \mathrm{n}=2 \\
\text { B. physalus } \mathrm{n}=2 \\
\text { B. } \text { omurai } \mathrm{n}=1^{2}\end{array}$ & 9 & B. edeni (GOMx) and B. borealis \\
\hline CHRNA1 $^{\mathrm{a}}$ & 344 & $\begin{array}{l}\text { B. edeni }(\mathrm{GOMx}) \mathrm{n}=1 \\
\text { B. borealis } \mathrm{n}=1 \\
\text { B. physalus } \mathrm{n}=2\end{array}$ & $11(3)$ & B. edeni (GOMx) and B. borealis \\
\hline $\mathrm{Fg}^{\mathrm{b}}$ & 308 & $\begin{array}{l}\text { B. edeni }(\mathrm{GOMx}) \mathrm{n}=1 \\
\text { B. } \text { borealis } \mathrm{n}=1 \\
\text { B. } \text { physalus } \mathrm{n}=1\end{array}$ & 3 & B. edeni (GOMx) and B. physalus \\
\hline $\mathrm{G} \mathrm{PD}^{\mathrm{a}}$ & $523(504)$ & $\begin{array}{l}\text { B. edeni }(\mathrm{GOMx}) \mathrm{n}=1 \\
\text { B. edeni } \mathrm{n}=1 \\
\text { B. borealis } \mathrm{n}=2 \\
\text { B. physalus } \mathrm{n}=3\end{array}$ & $5(1)$ & None \\
\hline $\mathrm{INT}^{\mathrm{b}}$ & 507 & $\begin{array}{l}\text { B. edeni }(\mathrm{GOMx}) \mathrm{n}=1 \\
\text { B. borealis } \mathrm{n}=1 \\
\text { B. physalus } \mathrm{n}=1 \\
\text { B. omurai } \mathrm{n}=1\end{array}$ & 8 & None \\
\hline $\mathrm{MGF}^{\mathrm{b}}$ & $552(504)$ & $\begin{array}{l}\text { B. edeni }(\mathrm{GOMx}) \mathrm{n}=1 \\
\text { B. edeni } i^{\mathrm{C}} \mathrm{n}=1 \\
\text { B. borealis } \mathrm{n}=2 \\
\text { B. physalus } \mathrm{n}=2\end{array}$ & 3 & $\begin{array}{l}\text { B. edeni (GOMx), B. edeni }{ }^{\mathrm{c}} \text {, } \\
\text { and } B \text {. borealis }\end{array}$ \\
\hline
\end{tabular}

variable position in a single individual, resulting in a total of 3 haplotypes for all the samples over the full length of the control region (936 bp). Haplotype and nucleotide diversity estimates (inclusive of the heteroplasmic haplotype) for the first $375 \mathrm{bp}$ were 0.166 and 0.000218 , respectively, and 0.224 and 0.000129 , respectively, for the full length of the control region. The 5 GOMx Bryde's whale samples that were sequenced shared the same full cytb sequence (1140 bp), and the cox 1 barcoding region $(731 \mathrm{bp})$ was also identical for all 5 whales. All sequences for all genes and taxa were submitted to GenBank (KJ586812KJ586820, KJ586848-KL586854).
We identified 25 to 52 fixed differences in the 375 bp control region alignment between the GOMx Bryde's whale haplotypes and sequences from Balaenoptera e. edeni, B. e. brydei, B. borealis, and $B$. omurai, and genetic distance estimates were correspondingly high (Table 2). Similarly, cox1 and cytb sequences exhibited multiple fixed differences between the GOMx Bryde's whales and these 4 taxa (Table 2). Net nucleotide divergence for the control region was $9.6 \%$ between the GOMx whales and B. e. edeni and $13 \%$ between GOMx whales and B. e. brydei.

Bayesian analysis of the $375 \mathrm{bp}$ control region alignment yielded well-supported clades for all Bryde's 
Table 2. Genetic divergence estimates for Bryde's whale Balaenoptera edeni, sei whale B. borealis, and Omura's whale B. omurai. (A) Net between-group divergence $\left(\mathrm{d}_{\mathrm{A}}\right.$; Nei 1987) corrected using the T3P model in 375 bp of the mitochondrial DNA control region is shown below the diagonal, and within-group divergence is shown along the diagonal. (B) Number of fixed differences (number of indels) between taxa in the $375 \mathrm{bp}$ control region alignment. (C) Number of fixed differences in $653 \mathrm{bp}$ of cox1 (below diagonal) and $421 \mathrm{bp}$ of cytb (above diagonal). N: number of individuals; $h$ : number of haplotypes; GOMx: Gulf of Mexico

\begin{tabular}{|c|c|c|c|c|c|c|c|}
\hline A) & $\mathrm{N}$ & $h$ & B. edeni GOMx & B. e. edeni & B. e. brydei & B. borealis & B. omurai \\
\hline B. edeni GOMx & 23 & 2 & 0 & & & & \\
\hline B. e. edeni & 19 & 5 & 0.096 & 0.004 & & & \\
\hline B. e. brydei & 22 & 13 & 0.130 & 0.099 & 0.014 & & \\
\hline B. borealis & 4 & 4 & 0.112 & 0.093 & 0.079 & 0.017 & \\
\hline B. omurai & 11 & 4 & 0.272 & 0.204 & 0.222 & 0.226 & 0.0025 \\
\hline B) & $\mathrm{N}$ & $h$ & B. edeni GOMx & B. e. edeni & B. e. brydei & B. borealis & B. omurai \\
\hline B. edeni GOMx & 23 & 2 & - & & & & \\
\hline B. e. edeni & 19 & 5 & 25 & - & & & \\
\hline B. e. brydei & 22 & 13 & 25 & $20(1)$ & - & & \\
\hline B. borealis & 4 & 4 & $26(1)$ & 20 (1) & $16(1)$ & - & \\
\hline B. omurai & 11 & 4 & $52(8)$ & $42(8)$ & $40(5)$ & $43(9)$ & - \\
\hline C) & $\mathrm{N}$ & $h$ & B. edeni GOMx & B. e. edeni & B. e. brydei & B. borealis & B. omurai \\
\hline B. edeni GOMx & 5 & 1 & - & 7 & 19 & 12 & 37 \\
\hline B. e. edeni & 3 & 2 & 13 & - & 17 & 9 & 39 \\
\hline B. e. brydei & 2 & 2 & 23 & 25 & - & 16 & 41 \\
\hline B. borealis & 1 & 1 & 24 & 18 & 26 & - & 38 \\
\hline B. omurai & 2 & 2 & 49 & 45 & 54 & 45 & - \\
\hline
\end{tabular}

whale taxa, including the GOMx whales (Fig. 3A). Each of the 3 sequences derived from specimens with morphological identifications (Sasaki et al. 2006) were placed in one of 3 well-supported clades allowing unequivocal identification of clades corresponding to B. e. edeni, B. e. brydei, and B. omurai. The GOMx haplotypes did not fall into any of these clades, but instead formed a single, well-supported group of their own, distinct from all other Bryde's whale haplotypes. Shortening the alignment to $305 \mathrm{bp}$ to incorporate haplotypes of $B$. e. brydei from additional geographic locations did not alter the tree topology, but did increase the support for the node joining $B$. e. edeni samples from GenBank and the GOMx Bryde's whale haplotypes (see Fig. S1 in the Supplement at www.int-res.com/articles/suppl/n025 p019_supp.pdf). Phylogenetic analysis of mtDNA protein coding genes produced similar results (Fig. 3B). Although each of the taxa was well supported, relationships among them were not, and applying a strict consensus model to the control-region phylogeny, collapsing nodes with posterior probability values $<0.95$, resulted in a polytomy for the Bryde's whale complex. Finally, the CAs analysis using the 9 diagnostic nucleotide positions identified by Kershaw et al. (2013) was unable to assign the GOMx Bryde's whales to either B. e. edeni or B. e. brydei. However, performing the CAs analysis on our 305 bp alignment identified multiple diagnostic nucleotide positions (Table 3) for each of the 4 taxa: $B$. e. edeni $(\mathrm{n}=2), B$. e. brydei $(\mathrm{n}=4), B$. omurai $(\mathrm{n}=13)$, and GOMx Bryde's whales $(\mathrm{n}=7)$.

Of the 54 microsatellite loci that were tested on the GOMx samples (see Table S1d in the Supplement), 12 were removed because they did not amplify at all $(\mathrm{n}=5)$, the amplification product was non-specific $(n=4)$, or they did not produce a stutter pattern typical of a dinucleotide repeat $(n=3)$. Twenty-five loci were monomorphic across all samples ( $\mathrm{n}=18$ to 23 ) tested. The remaining loci $(\mathrm{n}=17$; see Table $\mathrm{S} 1 \mathrm{e}$ in the Supplement) proved to be polymorphic, producing from 2 to 4 alleles (10 had 2 alleles, 6 had 3 alleles, and 1 had 4 alleles). No loci were out of HWE or showed evidence for linkage disequilibrium. Observed and expected heterozygosities were quite low (see Table S1e in the Supplement), with means $( \pm \mathrm{SD}$ ) over the 17 polymorphic loci of $0.256 \pm 0.201$ and $0.241 \pm 0.187$, respectively. Average allelic richness was 2.5 .

We sequenced a total of $4908 \mathrm{bp}$ from 9 nuclear loci (GenBank accession numbers KJ586821KKJ586847). Alignment with sequences from Gen- 


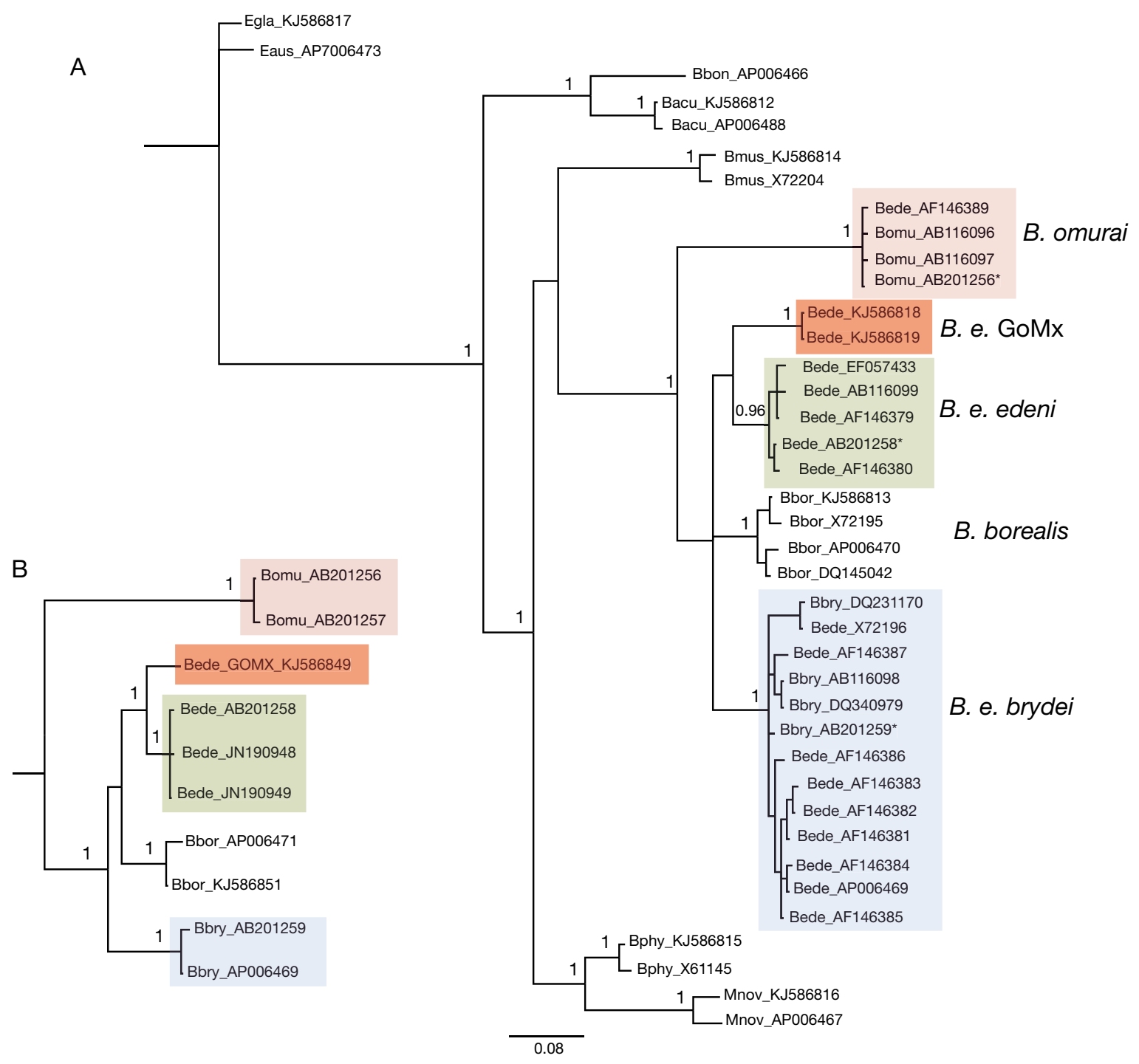

Fig. 3. Bayesian reconstruction of phylogenetic relationships among members of the Bryde's whale complex (Balaenoptera spp.). Posterior probabilities $>0.90$ are shown at nodes. (A) Control region haplotypes (375 bp). (B) Concatenated $c y t b-c o x 1$ sequences. ${ }^{*}$ Individuals morphologically identified to species by Sasaki et al. (2006) and used to identify the species clades. Colour shading indicates taxa of the same taxonomic group. Length of scale bar is proportional to the number of nucleotide substitutions per site. GenBank accession numbers with abbreviated species name provided in GenBank serve as branch tip identifiers - see Table S1a in the Supplement for all sequences that were collapsed to each haplotype. GOMx: Gulf of Mexico

Table 3. Characteristic attributes analysis of the Bryde's whale control region (305 bp) identifying 25 diagnostic sites for 4 taxa. $\mathrm{n}$ : total number of individuals examined for each species. Grayed cells identify sites diagnostic for a species. Nucleotide positions 15563-15769 correspond to the Balaenoptera edeni brydei mtDNA genome of GenBank accession no. AB201259

\begin{tabular}{|c|c|c|c|c|c|c|c|c|c|c|c|c|c|c|c|c|c|c|c|c|c|c|c|c|c|}
\hline & 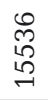 & 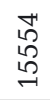 & $\begin{array}{l}0 \\
10 \\
10 \\
n\end{array}$ & 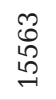 & $\begin{array}{l}n \\
0 \\
0 \\
10 \\
\sim\end{array}$ & 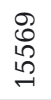 & 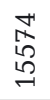 & $\begin{array}{l}n \\
\hat{\alpha} \\
2 \\
n \\
\sim\end{array}$ & $\begin{array}{l}\infty \\
\infty \\
\sim \\
i n \\
\sim \\
\sim\end{array}$ & $\begin{array}{l}10 \\
\infty \\
10 \\
10 \\
-1\end{array}$ & $\begin{array}{l}\infty \\
\infty \\
10 \\
10 \\
\sim\end{array}$ & 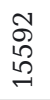 & 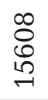 & 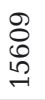 & $\begin{array}{l}m \\
\overrightarrow{6} \\
\stackrel{n}{-1}\end{array}$ & $\begin{array}{l}0 \\
\stackrel{1}{6} \\
\stackrel{\omega}{\rightarrow}\end{array}$ & $\begin{array}{l}\text { तె } \\
\text { \&ै } \\
\stackrel{n}{\sim}\end{array}$ & 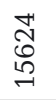 & 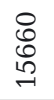 & 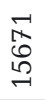 & 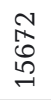 & 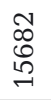 & 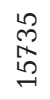 & $\begin{array}{l}0 \\
1 \\
10 \\
10\end{array}$ & $\begin{array}{l}\text { 8 } \\
0 \\
1 \\
1\end{array}$ \\
\hline B e. brydei $(\mathrm{n}=392)$ & $\mathrm{C}$ & A & $\mathrm{T}$ & $\mathrm{T}$ & $\mathrm{T}$ & $\mathrm{C}$ & $\mathrm{A}$ & $\mathrm{T}$ & $\mathrm{A}$ & $\mathrm{C}$ & $\mathrm{A}$ & $\mathrm{T}$ & $\mathrm{C}$ & $\mathrm{T}$ & G & G & $\mathrm{G}$ & $\mathrm{T}$ & $\mathrm{T}$ & G & $\mathrm{C}$ & $\mathrm{T}$ & A & $\mathrm{C}$ & A \\
\hline B. e. edeni $(\mathrm{n}=92)$ & * & * & $*$ & $\mathrm{C}$ & * & * & * & * & * & * & * & $\mathrm{C}$ & $*$ & $\mathrm{C}$ & * & $\mathrm{T}$ & $*$ & * & $*$ & * & * & $\mathrm{C}$ & * & * & $\mathrm{T}$ \\
\hline B. e. GOMx $(\mathrm{n}=21)$ & $*$ & $*$ & $*$ & ${ }^{*}$ & $*$ & $*$ & ${ }^{*}$ & $*$ & $*$ & $\mathrm{~T}$ & $*$ & * & $\mathrm{T}$ & $\mathrm{C}$ & $*$ & $\mathrm{~T}$ & A & $\mathrm{C}$ & $*$ & ${ }^{*}$ & * & $\mathrm{C}$ & $\mathrm{G}$ & $\mathrm{T}$ & $\mathrm{C}$ \\
\hline B. omurai $(\mathrm{n}=11)$ & $\mathrm{T}$ & G & $\mathrm{C}$ & * & $\mathrm{C}$ & $\mathrm{T}$ & $\mathrm{T}$ & $\mathrm{C}$ & $\mathrm{G}$ & $*$ & $\mathrm{G}$ & $*$ & $*$ & C & A & $\mathrm{T}$ & $*$ & $*$ & C & $\mathrm{T}$ & A & C & $*$ & * & $\mathrm{T}$ \\
\hline
\end{tabular}


Bank required some gene sequences to be shortened and, as a result, the total length of aligned nuclear genes was $4801 \mathrm{bp}$. Examination of the alignments for each gene revealed extraordinarily low variability among balaenopterid species examined (Table 1). In sum, there were 50 variable sites and 4 indels. CHRNA1 was the most variable locus. BDNF and INT also had a higher number of variable positions, but they both included sequence of the highly divergent $B$. omurai. In making these comparisons, we found that GenBank accession number AY954635 is likely from $B$. omurai, though it is labeled as B. edeni in GenBank. The mtDNA NAD3 gene sequence is also available for the same voucher specimen in GenBank (AY954648), and comparison via BLAST of this sequence with $B$. omurai of Sasaki et al. (2006) (which was identified morphologically) reveals 100\% identity and no substitutions over the $317 \mathrm{bp}$ length.

In 6 of the 9 nuclear loci, 2 or more species shared sequences. Bryde's whales from the GOMx shared alleles with the sei whale at 3 loci (MGF, CHRNA1, and BDNF) and with other Bryde's whales at ATP7; sei and fin whales shared sequence at ADRB2; Bryde's whales and sei whales shared an allele at MGF; while GOMx Bryde's whales and fin whales shared an allele at F9. Most of the variable positions identified the more divergent fin whale and/or Omura's whale.

\section{DISCUSSION}

We examined the genetic diversity of Bryde's whales sampled in the northern GOMx and their phylogenetic relationship to other members of the Bryde's whales complex. The GOMx whales exhibited very low levels of genetic diversity and were phylogenetically distinct from all other members of the Bryde's whale complex.

\section{Genetic diversity of GOMx Bryde's whales}

The only variability present in the $5^{\prime}$ end of the mtDNA control region among the 23 sampled whales was a single heteroplasmic position in 2 individuals. However, accepting the higher of the 2 bases at this position resulted in a haplotype identical to the other 21 individuals. Vollmer et al. (2011) carefully evaluated heteroplasmy in cetacean mtDNA control region sequences and, after ruling out artifacts from amplification, sequencing methods, and the presence of nuclear copies of mitochondrial genes, found that approximately $2 \%$ of the 5062 individuals sequenced were heteroplasmic. We re-sequenced both heteroplasmic individuals using a variety of primer pairs spanning the heteroplasmic position, and also extracted and sequenced DNA from both skin and muscle for one individual. All resultant sequences revealed the heteroplasmic position. Because of the redundant sequencing and the fact that this heteroplasmic position was found in 2 separate whales, we do not think it is an artifact. Sequencing the rest of the control region revealed only 1 additional variable site downstream of the first $375 \mathrm{bp}$ and present in a single individual. Wiseman (2008) found a similar result, with little added variability in the 3 ' end of the control region in Balaenoptera edeni brydei from New Zealand. Control-region haplotype and nucleotide diversities for the GOMx whales were therefore very low. Diversity estimates for other members of the genus Balaenoptera are substantially higher (Table 4), except perhaps for B. e. brydei from inshore waters of South Africa (Penry 2010) and B. e. edeni from the northern Indian Ocean (Kershaw et al. 2013).

A general pattern emerges that intraspecific variability in the $5^{\prime}$ end of the control region is significantly lower for B. e. edeni than for B. e. brydei. For the $375 \mathrm{bp}$ alignment, $B$. e. edeni haplotypes from India, Singapore, and Japan (Junge 1950, Yoshida \& Kato 1999, Wada et al. 2003, Sasaki et al. 2006, Jayasankar et al. 2009) exhibited 1 to 5 substitutions among them (average within-group divergence of $0.39 \%)$. The 45 B. e. edeni samples from Oman and Bangladesh (Kershaw et al. 2013) all shared the same haplotype over $299 \mathrm{bp}$ of the control region, although this increased to 2 haplotypes over a $407 \mathrm{bp}$ fragment (Kershaw et al. 2013). Similarly, for the GOMx whales, we identified 1 variable position (when including the heteroplasmic haplotype) in the first $375 \mathrm{bp}$ of the control region amongst 23 individuals. In contrast, Kanda et al. (2007) identified 38 polymorphic sites characterizing 51 haplotypes with an average inter-population sequence divergence of $0.77 \%$ for the first $299 \mathrm{bp}$ of the control region among $B$. e. brydei populations in the Pacific and eastern Indian Oceans. Similarly, Penry (2010) found levels of intraspecific sequence differentiation of $0.7-0.9 \%$ in a comparison of South African inshore Bryde's whale samples with B. e. brydei haplotypes from the western Pacific and eastern Indian Oceans.

Low levels of genetic diversity were also seen for the GOMx Bryde's whales at nuclear microsatellite loci, indicating that the low genetic variability was not restricted to the mtDNA genome. We tested 
Table 4. Summary of control region variability for balaenopterid whales. Length of sequence examined (bp), reported number of haplotypes $\left(\mathrm{N}_{\mathrm{H}}\right)$, haplotypic diversity $(h)$ and nucleotide diversity $(\pi)$ are shown. n/a: information not provided by authors

\begin{tabular}{|lcccccc|}
\hline Taxon & $\begin{array}{c}\text { Sample } \\
\text { size }\end{array}$ & bp & $\mathrm{N}_{\mathrm{H}}$ & $h$ & $\pi$ & Reference \\
\hline Balaenoptera edeni (GOMx) & 23 & 936 & 3 & 0.224 & $1.29 \times 10^{-4}$ & Present study \\
B. e. edeni (Bangladesh \& Oman) & 35 & 299 & 1 & 0.000 & 0 & Kershaw et al. (2013) \\
B. e. brydei (Inshore South Africa) & 26 & 685 & 6 & 0.363 & 0.0006 & Penry (2010) \\
B. e. brydei (Pacific Ocean) & 520 & 299 & 51 & 0.854 & 0.011 & Kanda et al. (2007) \\
B. e. brydei (Pacific) & 37 & 376 & 12 & $\mathrm{n} / \mathrm{a}$ & $\mathrm{n} / \mathrm{a}$ & Yoshida \& Kato (1999) \\
B. e. brydei (Maldives) & 8 & 299 & 4 & 0.750 & 0.005 & Kershaw et al. (2013) \\
B. e. brydei (New Zealand) & 49 & 373 & 10 & 0.65 & 0.007 & Wiseman (2008) \\
B. physalus (North Atlantic) & 402 & 288 & 51 & $0.96^{\mathrm{a}}$ & 0.013 & Bérubé et al. (1998) \\
B. musculus (Antarctic) & 183 & 410 & 52 & 0.968 & 0.014 & Sremba et al. (2012) \\
B. acutorostrata (North Atlantic) & 102 & 340 & 26 & $\mathrm{n} / \mathrm{a}$ & 0.006 & Pastene et al. (2007) \\
a Estimated from data in publication & & & & & &
\end{tabular}

54 loci (see Table S1d in the Supplement) shown to be polymorphic in other cetacean species, and after dropping 12 due to a lack of acceptable amplification, found 25 to be monomorphic and only 17 to be polymorphic in the GOMx Bryde's whale sample set. Furthermore, these polymorphic loci had at most 4 alleles, with an average of 2.5 alleles per locus, resulting in a mean observed heterozygosity of 0.256 . In comparison, Kanda et al. (2007), Wiseman (2008), and Penry (2010) averaged 9.3, 5.5, and 3.6 alleles per locus, respectively, in their studies of $B$. e. brydei populations, and all had higher observed heterozygosities.

Low genetic variability, particularly when found in both mitochondrial and nuclear genomes, is cause for concern. Genetic diversity is critical for populations and species to maintain evolutionary potential and to be able to adapt to environmental changes. Low genetic diversity is also associated with lowered reproductive fitness and survival. Reed \& Frankham (2003) found a significant correlation between heterozygosity and fitness in an examination of 34 different data sets (allozyme, morphological, and microsatellite) as well as between fitness and population size. The low genetic variability and small estimated population size for Bryde's whales in the GOMx therefore raises concern for the population's viability.

\section{Phylogenetic distinctiveness of Bryde's whales in the GOMx}

In addition to low overall levels of genetic diversity, Bryde's whales in the GOMx exhibit a phylogenetic distinctiveness equivalent to the other subspecies in the complex. The number of fixed differences in the
mtDNA protein coding genes and in the control region between the GOMx whales and $B$. e. edeni, $B$. e. brydei, B. borealis, and B. omurai was as high or higher than that observed between the 2 recognized $B$. edeni subspecies and that observed between either of these subspecies and B. borealis (Table 2). In the cox1 DNA barcoding region, we found 13 fixed differences between the GOMx whales and $B$. e. edeni sequences and 23 fixed differences between the GOMx whales and B. e. brydei sequences. The 2 recognized subspecies exhibited 25 fixed differences in this $653 \mathrm{bp}$ fragment, indicating that the GOMx population is as distinctive as the 2 recognized subspecies. Control-region sequences exhibited 25 fixed differences between the GOMx Bryde's whales and both B. e. edeni and B. e. brydei (Table 2). Penry (2010) report 1.9-2.3\% (uncorrected) sequence divergence over $658 \mathrm{bp}$ of the control region between B. e. brydei from South Africa and B. e. edeni individuals from coastal southwest Japan and Singapore. The $9.6 \%$ corrected sequence divergence seen between GOMx Bryde's whales and B. e. edeni far exceeds these values, indicating that the GOMx whales are more than simply another population of Bryde's whale.

Similar studies of other large whale species have found considerably lower numbers of fixed differences between subspecies and species than we found between GOMx Bryde's whales and other Bryde's whale taxa. For example, Rosenbaum et al. (2000) examined $292 \mathrm{bp}$ of the control region among the 3 right whale species and found 6 to 7 fixed differences between them. Archer et al. (2013) identified 1 fixed difference between North Atlantic and Southern Hemisphere fin whale subspecies and 2 between the North Atlantic and North Pacific popu- 
lations over the first $412 \mathrm{bp}$ of the control region. Not until the entire mitogenome was sequenced did the number of fixed differences exceed 20. The authors suggest that the level of differentiation found between North Atlantic and North Pacific fin whale populations warrants subspecies status. The number of fixed differences in the combined cox1, cytb (1074 $\mathrm{bp})$, and first $375 \mathrm{bp}$ of the control region between GOMx Bryde's whales and all available $B$. e. edeni sequences is 45 (Table 2), significantly exceeding those seen among the right and fin whale species and subspecies.

The Bayesian phylogenetic analyses identified the GOMx Bryde's whale haplotypes as phylogenetically distinct (Fig. 3), and the CAs analysis identified 7 diagnostic nucleotide positions in the $305 \mathrm{bp}$ control region alignment separating GOMx haplotypes from those of B. e. edeni, B. e. brydei, and B. omurai. GOMx haplotypes always formed a clade of their own, separate from all other taxa, regardless of the mtDNA locus that was used. GOMx whales were sister to $B$. e. edeni, in the concatenated cytb-cox1 phylogeny with a posterior probability of 1.0. Control-region phylogenies also placed the GOMx clade sister to $B$. e. edeni from the Indian and western Pacific Oceans, but with no support. In fact, the control region trees produced polytomies (when collapsing posterior probabilities of less than 0.95) of the 2 B. edeni subspecies, $B$. borealis, and the GOMx Bryde's whale, where each species or subspecies was well supported but the relationships among them were not. Thus, while the GOMx Bryde's whale is phylogenetically distinct from all other members of the Bryde's whale complex, a fully resolved phylogeny settling the evolutionary relationship among members of this group awaits further data.

In addition to the phylogenetic distinctiveness of GOMx Bryde's whales, their size (total length) also seems to be unique. Jefferson (1995) and Jefferson \& Schiro (1997) re-examined stranding records for many cetacean species in the GOMx. For the Bryde's whale, they verified 11 stranding records; we can add 3 new verified records for whales that have stranded since the mid-1990s. Both sexes, as well as both calf and adult size classes, have been found. Of the verified records, the largest whale was a $12.65 \mathrm{~m}$ lactating female, and there were 4 additional whales with lengths between 11.2 and $11.6 \mathrm{~m}$. Unfortunately, information on physical maturity is not available for these whales. However, if these strandings are representative of the GOMx taxon, then these whales seem to fall into a size range intermediate between $B$. e. edeni and $B$. e. brydei as defined by Rice (1998). There is a need for future morphological studies on Bryde's whale specimens from the GOMx.

Finally, Rice et al. (2014) recently reported new acoustic data for Bryde's whales in the northeastern GOMx. Recorded vocalizations were consistent with but differed from those previously reported for Bryde's whales elsewhere, supporting the genetic result that these whales represent an evolutionarily distinct unit.

\section{Geographic distribution of Bryde's whale taxa}

Rice (1998) provides a thorough summary of the history and many causes of confusion for the taxonomy of the Bryde's whale complex. He attributes all records of Bryde's whales in the Atlantic Ocean to the larger form, namely B. e. brydei. Analysis of Bryde's whales from South Africa support Rice's conclusion as both inshore and offshore forms identified by Best $(1977,2001)$ are genetically more closely related to B. e. brydei (Penry 2010). Soot-Ryen (1961) described a large Bryde's whale from Curaçao and, based on morphological comparison, identified it as B. brydei. The whale was estimated at $13.5 \mathrm{~m}$ total length, in line with Rice's (1998) description of B. e. brydei. de Moura \& Siciliano (2012) examined stranding records from the South Atlantic coast of Brazil and identified 46 Bryde's whales. Of the 39 with measurements, $27 \%$ were $\geq 13 \mathrm{~m}$ and $46 \%$ were $\geq 12 \mathrm{~m}$ in length. Both female and male specimens of 14 and $15 \mathrm{~m}$ were identified. A whale stranded in Venezuela in 1963 was estimated at greater than $13 \mathrm{~m}$ long (Notarbartolo di Sciara 1983). The sizes for all these whales exceed that expected for B. e. edeni (Rice 1998), suggesting, as concluded by Soot-Ryen (1961) for the Curaçao whale, that they represent B. e. brydei. Thus, to date, information from morphological data based on stranding records in the Atlantic Ocean has suggested that only $B$. e. brydei is present.

We examined locality information for $B$. e. edeni and $B$. e. brydei samples used in molecular phylogenetic studies and connected their phylogenetic position on the control region tree to geographic sampling location (Fig. 4). The B. e. brydei clade exhibited a much wider geographic distribution, being found broadly in offshore waters of the Northwest Pacific, in the South Pacific south of Fiji and off Peru, in the eastern Indian Ocean south of Java (Yoshida \& Kato 1999, Wada et al. 2003, Sasaki et al. 2005, Sasaki et al. 2006, Kanda et al. 2007), off Sri Lanka, Oman, and the Maldive Islands in the north- 

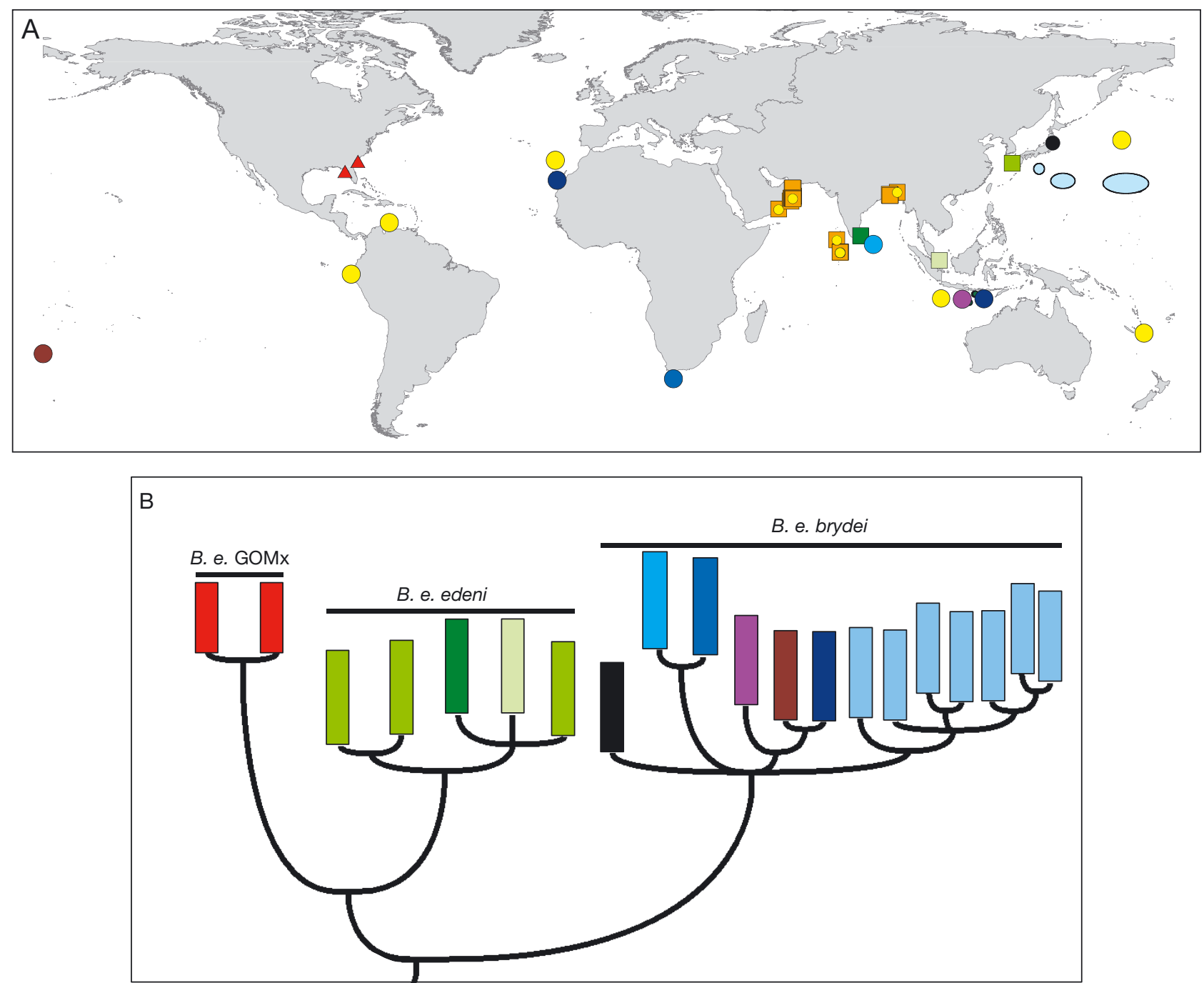

Fig. 4. Relationship between geographic sampling location and phylogenetic position for Bryde's whale control-region haplotypes. (A) Geographic sampling locations for Bryde's whale control-region haplotypes identified in this and previous publications (see Table S1a in the Supplement). Circles/ovals identify locations of haplotypes phylogenetically identified as Balaenoptera edeni brydei, squares represent haplotypes phylogenetically identified as $B$. e. edeni, and triangles represent haplotypes from the Gulf of Mexico (GOMx)/western North Atlantic Ocean. (B) Bayesian reconstruction of 375 bp controlregion alignment (modified from Fig. 3). Colored bars on tips of branches correspond to the colored symbols in (A) to illustrate geographic locations of haplotypes. Also included in (A) are sampling locations for multiple Bryde's whale control-region haplotypes too short to be included in the phylogeny in (B), but which clustered with subspecies $B$. e. edeni (orange squares) or B. e. brydei (yellow circles) in a 305 bp phylogeny (see Fig. S1 in the Supplement)

ern Indian Ocean (Herath 2007, Kershaw et al. 2013), in both inshore and offshore waters of South Africa (Árnason et al. 1993, Penry 2010), in the Atlantic at Madeira (Alves et al. 2010), and the Canary Islands (S. Hildebrandt et al. unpublished, GenBank accession no. DQ340979). Most recently, Luksenburg (2012) sequenced the control region of 2 unidentified balaenopterid whales that stranded in Aruba and found that these sequences fell within a well-supported $B$. e. brydei clade, most similar to 'offshore' Bryde's whales from South Africa and Madeira. In contrast,
$B$. e. edeni sequences have been found only in the northern Indian Ocean - in Oman and Bangladesh (Kershaw et al. 2013), off the southeast coast of India near Sri Lanka (Jayasankar et al. 2009), and in Pulu Sugi, Indonesia, near Singapore (Junge 1950, Wada et al. 2003) - and in the western North Pacific in coastal waters of southwestern Japan (Yoshida \& Kato 1999, Sasaki et al. 2006). The GOMx Bryde's whales appear to be phylogenetically most closely related to $B$. e. edeni based on the mtDNA data presented here. Thus, these whales may represent the 
first records for $B$. e. edeni or $B$. e. edeni-like whales in the Atlantic Ocean. Further work is necessary in the Atlantic to examine the distribution of Bryde's whales, particularly B. e. edeni, for which few samples have been examined using molecular genetic techniques. Given the difficulties in distinguishing sei whales from Bryde's whales, sei whale records should be re-examined as well.

\section{Historical presence of Bryde's whales in the GOMx}

Yankee whalers who utilized the GOMx made note of and killed baleen whales in the GOMx as early as the late 1700s (Reeves et al. 2011). While sperm whales were the primary target, other species were also hunted and logbooks recorded 'finbacks' being taken (Reeves et al. 2011). However, Jefferson \& Schiro (1997) found only 7 reliable records of fin whales in the GOMx. In addition, no verified sightings of fin, sei, or minke whales were recorded in US waters of the GOMx during National Marine Fisheries Service marine mammal ship surveys between 1994 and 2013 (Maze-Foley \& Mullin 2006, K. Mullin pers. comm.). Reeves et al. (2011) concluded that since Bryde's whales are the only balaenopterid whale occurring year-round in the GOMx and other balaenopterid species are rare, it is likely that the 'finbacks' taken by Yankee whalers were most commonly Bryde's whales. Interestingly, the authors found that the whaling logbook records suggest the species had a broader distribution in the GOMx than is seen today. The most notable difference in distribution lies in shelf waters south and west of the Mississippi River Delta, of which logbooks contain numerous records. Marine mammal surveys have never recorded confirmed Bryde's whale sightings from south and west of the Mississippi Delta, despite considerable survey effort. There are 2 records of 'sei/Bryde's' whale sightings in the early 1990s on the continental slope south of western Louisiana (Hansen et al. 1996; K. Mullin pers. comm.), but definitive species identifications were not made. Whether the apparent range contraction is accompanied by a decrease in abundance is unknown as there are no abundance estimates for the GOMx before the 1990s. It may be worth noting that energy exploration and production in the GOMx peaks in shelf and slope waters west of the Mississippi River Delta. This habitat disruption, along with associated noise, seismic activity, and vessel traffic, could have resulted in the abandonment of the northwestern GOMx by Bryde's whales.

\section{Conservation concern}

In 2011, the GOMx produced $18 \%$ of the US total commercial fishery production by ton (www.st.nmfs. noaa.gov/commercial-fisheries/commercial-landings/ annual-landings/index, accessed 23 February 2014). In addition, energy (oil and gas) exploration and production in the northern and western GOMx is higher than anywhere else in the USA. The GOMx supplied $55 \%$ of the total annual US production of crude oil between 2009 and 2011 (http://stateofthecoast.noaa. gov/energy/gulfenergy.html, accessed 23 February 2014). More than 3000 active oil and gas platforms operate in waters out to $\sim 200 \mathrm{~m}$ depth and there is $\sim 40000 \mathrm{~km}$ of pipeline in coastal waters west of Alabama (http://stateofthecoast.noaa.gov/energy/gulf energy.html, accessed 23 February 2014). There is no active energy exploration in the northeastern GOMx, where Bryde's whales are regularly seen, but should that change, the presence and status of this population should be carefully considered. Finally, large whales are vulnerable to ship strikes (Laist et al. 2001) and there is a considerable amount of large vessel traffic in the GOMx (National Ocean Service 2011). Ship strikes are documented in the GOMx and have been identified as the cause of death for at least one stranded Bryde's whale (NOAA National Marine Mammal Health and Stranding Response Database, unpublished data).

Bryde's whales are the only known resident baleen whale species in the northern GOMx, and hence they are a unique component of the biodiversity in this ecosystem. The current best estimate of abundance for US waters of the GOMx is $33(\mathrm{CV}=1.07)$, based on systematic ship-based surveys (Waring et al. 2013). All contemporary sightings have been restricted to the northeastern GOMx along the $200 \mathrm{~m}$ isobath. This low abundance is consistent with the extremely low levels of genetic diversity found in both the mtDNA and nuclear genomes, and places these whales at risk from decreased fitness and evolutionary potential, and demographic stochasticity (Rosel \& Reeves 2000). The high level of genetic divergence of GOMx Bryde's whales when compared with the 2 recognized Bryde's whale subspecies and other balaenopterids suggests that they have been isolated for a relatively long period of time. The combination of low genetic diversity, low population size, restricted distribution, and multiple potential sources for human-induced mortality elevates the level of concern for this population.

As the taxonomic uncertainties surrounding the Bryde's whale complex are further explored and set- 
tled through morphological and/or molecular genetic analyses, particularly nuclear DNA markers, the GOMx population should be included. Should a decision be made to elevate $B$. e. edeni and $B$. e. brydei to species status, the GOMx taxon must also be considered and may also warrant species or subspecies status. If such elevation were warranted, it could make the GOMx whales one of the most endangered of the baleen whales. Our knowledge of the distribution of this taxonomic unit is incomplete, but based on whales sampled in the South Atlantic off Africa (Penry 2010) and whales examined from Brazil (de Moura \& Siciliano 2012), Curaçao (Soot-Ryen 1961), and Aruba (Luksenburg 2012), we can say that it likely does not reach that far. Of note, however, is that the 2 samples collected on the US Atlantic coast for the present study also shared the mtDNA haplotype found in the GOMx. Thus, the population may occupy a larger geographic area or, as suggested by Mead (1997), these whales may have simply strayed from the GOMx. Ongoing work may help clarify whether the GOMx type of Bryde's whale is present in the northern Caribbean and will further address the level of differentiation in the nuclear genome between GOMx Bryde's whales and the other recognized subspecies. Given the potential for a variety of anthropogenic impacts, a complete understanding of the relationship of this genetically unique, small resident GOMx population to Bryde's whales elsewhere is of great importance.

Acknowledgements. We gratefully acknowledge K. Mullin and L. Stratton (National Marine Fisheries Service [NMFS], Southeast Fisheries Science Center [SEFSC]) for their invaluable help with historical records of Bryde's whales in the Gulf of Mexico. K. Mullin also kindly provided the photo (Fig. 1), which was taken by W. Hoggard, NMFS SEFSC, under Marine Mammal Protection Act (MMPA) Permit 738 (P77 \#51). We thank members of the Southeast United States (SEUS) stranding network, who diligently respond to stranded marine mammals, particularly S. Bowen (NMFS, SEFSC), K. Brill (Florida Fish and Wildlife Conservation Commission), W. McLellen (University of North Carolina, Wilmington), and B. Sima (Audubon Aquarium of the Americas), who responded to Bryde's whale strandings. For biopsy collection, we thank K. Mullin, A. Martinez, J. Wicker, K. Barry (NMFS, SEFSC), and members of the field crews involved in surveys to collect samples. Base maps come from NOAA National Geophysical Data Center (NGDC). Biopsy samples were collected under MMPA Permit Nos 779-1339 MMPA and 779-1633 issued to the NMFS Southeast Fisheries Science Center.

\section{LITERATURE CITED}

Adams L, Rosel P (2006) Population differentiation of the Atlantic spotted dolphin (Stenella frontalis) in the western North Atlantic, including the Gulf of Mexico. Mar Biol 148:671-681
Agnarsson I, May-Collado L (2008) The phylogeny of Cetartiodactyla: the importance of dense taxon sampling, missing data, and the remarkable promise of cytochrome b to provide reliable species-level phylogenies. Mol Phylogenet Evol 48:964-985

Alves F, Dinis A, Cascão I, Freitas L (2010) Bryde's whale (Balaenoptera brydei) stable associations and dive profiles: new insights into foraging behavior. Mar Mamm Sci 26:202-212

Amante C, Eakins BW (2009) ETOPO1 1 Arc-Minute Global Relief Model: procedures, data sources and analysis. NOAA Tech Memo NESDIS NGDC-24. National Geophysical Data Center, NOAA, Boulder, CO, doi:10.7289/ V5C8276M

Anderson J (1878 [1879]) Comprising an account of the zoological results of the two expeditions to western Yunnan in 1868 and 1875; and a monograph of the two cetacean genera, Platanista and Orcella. Quaritch, B., London

- Archer FI, Morin PA, Hancock-Hanser BL, Robertson KM and others (2013) Mitogenomic phylogenetics of fin whales (Balaenoptera physalus spp.): genetic evidence for revision of subspecies. PLoS ONE 8:e63396

Árnason Ú, Gullberg A, Widegren B (1993) Cetacean mitochondrial DNA control region sequences of all extant baleen whales and two sperm whale species. Mol Biol Evol 10:960-970

Bérubé M, Palsbøll P (1996) Identification of sex in cetaceans by multiplexing with three ZFX and ZFY specific primers. Mol Ecol 5:283-287

- Bérubé M, Aguilar A, Dendanto D, Larsen F and others (1998) Population genetic structure of North Atlantic, Mediterranean Sea and Sea of Cortez fin whales, Balaenoptera physalus (Linnaeus 1758): analysis of mitochondrial and nuclear loci. Mol Ecol 7:585-599

Best PB (1960) Further information on Bryde's whale (Balaenoptera edeni Anderson) from Saldanha Bay, South Africa. Norsk Hvalfangst-Tidende 49:201-215

Best PB (1977) Two allopatric forms of Bryde's whale off South Africa. Rep Int Whal Comm 1:10-38

> Best PB (2001) Distribution and population separation of Bryde's whale Balaenoptera edeni off southern Africa. Mar Ecol Prog Ser 220:277-289

Committee on Taxonomy (2011) List of marine mammal species and subspecies. Society for Marine Mammalogy, www.marinemammalscience.org (accessed on 4 March 2013)

Davis JI, Nixon KC (1992) Populations, genetic variation, and the delimitation of phylogenetic species. Syst Biol 41:421-435

de Moura JF, Siciliano S (2012) Stranding pattern of Bryde's whales along the south-eastern coast of Brazil. Mar Biodivers Rec 5:e73

> Edgar RC (2004) MUSCLE: multiple sequence alignment with high accuracy and high throughput. Nucleic Acids Res 32:1792-1797

> Excoffier L, Lischer HEL (2010) Arlequin suite ver 3.5: a new series of programs to perform population genetics analyses under Linux and Windows. Mol Ecol Resour 10: 564-567

Goudet J (1995) FSTAT (version 1.2): a computer program to calculate F-statistics. J Hered 86:485-486

Hansen LJ, Mullin KD, Jefferson TA, Scott GP (1996) Visual surveys aboard ships and aircraft. In: Davis RW, Fargion GS (eds) Distribution and abundance of marine mammals in the north-central and western Gulf of Mexico. Final Re- 
port Vol II: Tech Rep OCS Study MMS 96-0027. US Department of the Interior, Minerals Management Service, Gulf of Mexico OCS Region, New Orleans, LA, p 55-132

Herath DR (2007) Identification of a stranded whale by mitochondrial DNA analysis - www.DNA-Surveillance program in action. Asian Fish Sci 20:319-324

> Huelsenbeck JP, Ronquist F (2001) MRBAYES: Bayesian inference of phylogenetic trees. Bioinformatics 17:754-755

Irwin DM, Kocher TD, Wilson AC (1991) Evolution of the cytochrome $b$ gene of mammals. J Mol Evol 32:128-144

IUCN (2012) IUCN Red List of Threatened Species. Version 2012.2. www.iucnredlist.org (accessed on 25 April 2013)

Jayasankar P, Anoop B, Rajagopalan M, Yousuf KMM and others (2009) Indian efforts on the inventorization of marine mammal species for their conservation and management. Asian Fish Sci 22:143-155

Jefferson TA (1995) Distribution, abundance and some aspects of the biology of cetaceans in the offshore Gulf of Mexico. PhD dissertation, Texas A \& M University, College Station, TX

Jefferson TA, Schiro AJ (1997) Distribution of cetaceans in the offshore Gulf of Mexico. Mammal Rev 27:27-50

Junge GCA (1950) On a specimen of the rare fin whale, Balaenoptera edeni Anderson, stranded on Pulu Sugi near Singapore. Zool Verh 9:1-26

Kanda N, Goto M, Kato H, McPhee MV, Pastene LA (2007) Population genetic structure of Bryde's whales (Balaenoptera brydei) at the inter-oceanic and trans-equatorial levels. Conserv Genet 8:853-864

Kato H, Perrin WF (2009) Bryde's whales Balaenoptera edeni/brydei. In: Perrin WF, Würsig B, Thewissen JG (eds) Encyclopedia of marine mammals. Academic Press, San Diego, CA, p 158-163

Kershaw F, Leslie MS, Collins T, Mansur RM and others (2013) Population differentiation of 2 forms of Bryde's whales in the Indian and Pacific Oceans. J Hered 104: 755-764

> Kocher TD, Thomas WK, Meyer A, Edwards SV, Pääbo S, Villablanca FX, Wilson AC (1989) Dynamics of mitochondrial DNA evolution in animals: amplification and sequencing with conserved primers. Proc Natl Acad Sci USA 86:6196-6200

Laist DW, Knowlton AR, Mead JG, Collet AS, Podesta M (2001) Collisions between ships and whales. Mar Mamm Sci 17:35-75

> Lopes RFF, Senna JPM, Chies HM, Rodriques JL (1999) Pitstop PCR: an approach to increase final product yield of multiplex PCR. Biotechniques 26:638-639

Lowenstein JH, Amato G, Kolokotronis SO (2009) The real maccoyii: identifying tuna sushi with DNA barcodescontrasting characteristic attributes and genetic distances. PLoS ONE 4:e7866

Luksenburg JA (2012) The cetaceans of Aruba: a multidisciplinary study. PhD dissertation, George Mason University, Fairfax, VA

Maddison DR, Maddison WP (2000) MacClade 4: analysis of phylogeny and character evolution. Version 4.0. Sinauer Associates, Sunderland, MA

Maze-Foley K, Mullin KD (2006) Cetaceans of the oceanic northern Gulf of Mexico: Distributions, group sizes and interspecific associations. J Cetacean Res Manag 8: 203-213

> McGowen MR, Gatesy J (2009) Divergence date estimation and a comprehensive molecular tree of extant cetaceans. Mol Phylogenet Evol 53:891-906
Mead JG (1997) Records of sei and Bryde's whales from the Atlantic coast of the United States, the Gulf of Mexico, and the Caribbean. Rep Int Whal Comm 1(Special Issue): 113-116

Miller MA, Pfeiffer W, Schwartz T (2010) Creating the CIPRES Science Gateway for inference of large phylogenetic trees. Proceedings of the Gateway Computing Environments Workshop (GCE), New Orleans, LA

National Ocean Service (2011) The Gulf of Mexico at a glance: a second glance. US Department of Commerce, National Oceanic and Atmospheric Administration, Washington, DC

Nei M (1987) Molecular evolutionary genetics. Columbia University Press, New York, NY

- Nei M, Tajima F (1981) DNA polymorphism detectable by restriction endonucleases. Genetics 97:145-163

Notarbartolo di Sciara G (1983) Bryde's whale (Balaenoptera edeni Anderson, 1878) off Eastern Venezuela (Cetacea, Balaenopteridae). Hubbs-Sea World Research Inst Tech Rep 83-153. Hubbs-Sea World Research Institute, San Diego, CA

Olsen Ö (1913) On the external characters and biology of Bryde's whale (Balaenoptera brydei), a new rorqual from the coast of South Africa. Proc Zool Soc Lond 1913: 1073-1090

Palumbi S, Martin A, Romano S, McMillan WO, Stice L, Grabowski G (1991) The simple fool's guide to PCR. University of Hawaii, Honolulu, HI

Park SDE (2001) Trypanotolerance in West African cattle and the population genetic effects of selection. PhD dissertation, University of Dublin

Pastene LA, Goto M, Kanda N, Zerbini AN and others (2007) Radiation and speciation of pelagic organisms during periods of global warming: the case of the common minke whale, Balaenoptera acutorostrata. Mol Ecol 16: 1481-1495

> Peakall R, Smouse PE (2006) GENALEX 6: genetic analysis in Excel. Population genetic software for teaching and research. Mol Ecol Notes 6:288-295

Penry GS (2010) The biology of South African Bryde's whales. PhD dissertation, University of St. Andrews

Perrin WF, Dolar MLL, Ortega E (1996) Osteological comparison of Bryde's whales from the Philippines with specimens from other regions. Rep Int Whal Comm 46:409-413

> Posada D (2008) jModelTest: Phylogenetic model averaging. Mol Biol Evol 25:1253-1256

Rambaut A, Drummond A (2007) Tracer v1.4. Available at http://tree.bio.ed.ac.uk/software/tracer/

Reed DH, Frankham R (2003) Correlation between fitness and genetic diversity. Conserv Biol 17:230-237

Reeves RR, Lund JN, Smith TD, Josephson EA (2011) Insights from whaling logbooks on whales, dolphins, and whaling in the Gulf of Mexico. Gulf Mex Sci 29:41-67

Rice DW (1998) Marine mammals of the world. Systematics and distribution. The Society for Marine Biology, Allen Press, Lawrence, KS

Rice A, Palmer K, Tielens J, Muirhead C, Clark C (2014) Potential Bryde's whale (Balaenoptera edeni) calls recorded in the northern Gulf of Mexico. J Acoust Soc Am 135:3066-3076

> Rosel PE, Block BA (1996) Mitochondrial control region variability and global population structure in the swordfish, Xiphias gladius. Mar Biol 125:11-22

Rosel PE, Reeves RR (2000) Genetic and demographic considerations for the conservation of Asian river cetaceans. 
In: Reeves RR, Smith BD, Kasuya T (eds) Biology and conservation of freshwater cetaceans in Asia. IUCN, Gland, p 144-152

Rosel PE, Dizon AE, Heyning JE (1994) Genetic analysis of sympatric morphotypes of common dolphins (genus Delphinus). Mar Biol 119:159-167

Rosel PE, Tiedemann R, Walton M (1999) Genetic evidence for limited trans-Atlantic movements of the harbor porpoise, Phocoena phocoena. Mar Biol 133:583-591

Rosenbaum HC, Brownell RL, Jr, Brown MW, Schaeff C and others (2000) World-wide genetic differentiation of Eubalaena: questioning the number of right whale species. Mol Ecol 9:1793-1802

Rousset F (2008) genepop'007: a complete re-implementation of the genepop software for Windows and Linux. Mol Ecol Resour 8:103-106

Sarkar IN, Thornton JW, Planet PJ, Figurski DH, Schierwater B, DeSalle R (2002) An automated phylogenetic key for classifying homeoboxes. Mol Phylogenet Evol 24:388-399

Sasaki T, Nikaido M, Hamilton H, Goto M and others (2005) Mitochondrial phylogenetics and evolution of mysticete whales. Syst Biol 54:77-90

Sasaki T, Nikaido M, Wada S, Yamada TK, Cao Y, Hasegawa M, Okada N (2006) Balaenoptera omurai is a newly discovered baleen whale that represents an ancient evolutionary lineage. Mol Phylogenet Evol 41:40-52

Soot-Ryen T (1961) On a Bryde's whale stranded on Curaçao. Norsk Hvalfangst-Tidende 50:323-332

Sremba AL, Hancock-Hanser B, Branch TA, LeDuc RL, Baker CS (2012) Circumpolar diversity and geographic differentiation of mtDNA in the critically endangered Antarctic blue whale (Balaenoptera musculus intermedia). PLoS ONE 7:e32579

Tamura K (1992) Estimation of the number of nucleotide substitutions when there are strong transition-transversion and $\mathrm{G}+\mathrm{C}$-content biases. Mol Biol Evol 9:678-687

Tamura K, Peterson D, Peterson N, Nei M, Kumar S (2011) MEGA5: molecular evolutionary genetics analysis using maximum likelihood, evolutionary distance, and maximum parsimony methods. Mol Biol Evol 28:2731-2739

Tolley KA, Rosel PE (2006) Population structure and histori-

Editorial responsibility: Paolo Casale, Rome, Italy cal demography of eastern North Atlantic harbour porpoises inferred through mtDNA sequences. Mar Ecol Prog Ser 327:297-308

Van Oosterhout C, Hutchinson WF, Wills DPM, Shipley P (2004) Micro-checker: software for identifying and correcting genotyping errors in microsatellite data. Mol Ecol Notes 4:535-538

Viricel A, Rosel PE (2012) Evaluating the utility of $\operatorname{cox} 1$ for cetacean species identification. Mar Mamm Sci 28:37-62

Vollmer NL, Rosel PE (2012) Developing genomic resources for the common bottlenose dolphin (Tursiops truncatus): isolation and characterization of 153 single nucleotide polymorphisms and 53 genotyping assays. Mol Ecol Resour 12:1124-1132

> Vollmer NL, Viricel A, Wilcox L, Moore MK, Rosel PE (2011) The occurrence of mtDNA heteroplasmy in multiple cetacean species. Curr Genet 57:115-131

Wada S, Oishi M, Yamada TK (2003) A newly discovered species of living baleen whale. Nature 426:278-281

> Waits LP, Luikart G, Taberlet P (2001) Estimating the probability of identity among genotypes in natural populations: cautions and guidelines. Mol Ecol 10:249-256

Waring GT, Josephson E, Maze-Foley K, Rosel PE (2013) US Atlantic and Gulf of Mexico Marine Mammal Stock Assessments - 2012. NOAA Tech Memo NMFS-NE-223. Northeast Fisheries Science Center, Woods Hole, MA

Wiseman N (2008) Genetic identity and ecology of Bryde's whales in the Hauraki Gulf, New Zealand. PhD dissertation, University of Auckland

Yamada TK, Chou LS, Chantrapornsyl S, Adulyanukosol K and others (2006) Middle sized balaenopterid whale specimens (Cetacea: Balaenopteridae) preserved at several institutions in Taiwan, Thailand, and India. Mem Natn Sci Mus Tokyo 44:1-10

Yamada TK, Kakuda T, Tajima Y (2008) Middle sized balaenopterid whale specimens in the Philippines and Indonesia. Mem Natn Sci Mus Tokyo 45:75-83

> Yoshida H, Kato H (1999) Phylogenetic relationships of Bryde's whales in the western north Pacific and adjacent waters inferred from mitochondrial DNA sequences. Mar Mamm Sci 15:1269-1286

Submitted: March 26, 2013; Accepted: April 2, 2014 Proofs received from author(s): July 2, 2014 